\title{
COMBINED EFFECT OF MICROENCAPSULATED HORSERADISH JUICE AND HIGH-PRESSURE TREATMENT ON PORK QUALITY DURING STORAGE
}

\author{
Sanita Sazonova ${ }^{1, \#}$, Lolita Tomsone ${ }^{1}$, Ruta Galoburda ${ }^{1}$, Ilze Grāmatina ${ }^{1}$, \\ and Thierry Talou ${ }^{2}$ \\ ${ }^{1}$ Faculty of Food Technology, Latvia University of Life Sciences and Technologies, 22 Rīgas Str., Jelgava, LV-3001, LATVIA \\ 2 Engineering Faculty of Life Sciences, Institut National Polytechnique de Tolouse, 4 All. Emile Monso, 31029, Tolouse, FRANCE \\ \# Corresponding author, sanita.sazonova@ @lu.Iv
}

Communicated by Sandra Muižniece-Brasava

\begin{abstract}
High-pressure processing (HPP) is well suited to combine consumer demand for meat products with minimal heat treatment without compromising product safety. In turn, herbs have antioxidant and antimicrobial properties. The aim of this study was to evaluate the application of hurdle technology combining microencapsulated horseradish root and leaf juice with HPP (300 MPa; $15 \mathrm{~min}$ ) for extending of the raw pork meat shelf life. Water activity $\left(a_{w}\right), p H$, colour, hardness, and microbiological parameters of meat were evaluated during 21-day storage. Total plate count (TPC) in HPP treated samples was significantly smaller $(\mathrm{p}<0.05)$ compared to untreated samples during storage until the day 14. On day 21, the TPC in processed samples was still slightly lower, however, at this point significance was not established between samples. Water activity dynamics in the HPP-treated microencapsulated pork meat samples differed significantly from other samples. Hardness decreased during storage, but no significant differences were found between samples. The $L^{*}$ values and $\mathrm{pH}$ of the meat were not significantly influenced by the added microencapsulated juice, but by high pressure treatment. Treatment with microencapsulated horseradish juice had a positive effect on the TPC and $a_{w}$ of the meat sample.
\end{abstract}

Key words: pork, horseradish roots and leaves, HPP, shelf life.

\section{INTRODUCTION}

Consumers are paying more and more attention to quality food and generally prefer minimally processed, fresh products with a natural taste and longer shelf life (Yordanov and Angelova, 2010; Merlino et al., 2018; Torrico et al., 2018; Oliveira et al., 2020). The main goal of meat processing is to reduce the spoilage and increase the shelf life of the final product. Through heat treatment, meat products are still subjected to chemical reactions that cause their degradation, changes in colour, taste, and aroma, which affects the quality of the product. An alternative to inhibit spoilage processes is the use of microcapsules that contain valuable ingredients such as natural antioxidants, probiotics, plant extracts with antioxidants, and antimicrobial agents (da Silva Anthero et al., 2021).

Plants are an excellent source of natural biologically active compounds, as they are rich in phenolic compounds with various antioxidant properties (Naczk and Shahidi, 2004). Numerous studies have already been carried out around the world on the addition of plant products, by-products and extracts to various food matrices, with the aim of improving their nutritional and biological value. However, an in-depth study of new sources of the valuable substances is worthwhile, as each plant has a specific and different profile and properties of the biologically active compounds. Consequently, their behaviour and effectiveness in specific food matrices also differ.

Horseradish (Armoracia rusticana L.) is a perennial plant of the family Brassicaceae growing in temperate latitudes. Plants of this genus, such as broccoli, spinach, cabbage, etc. contain biologically active compounds like phenolic compounds, glucosinolates, and various enzymes with antioxidant and anti-carcinogenic effects (Medjakovic et al., 2011; Bertóti et al., 2019; Wang et al., 2020). Horseradish does 
not require special growing conditions and is used in both cooking and folk medicine. Previous studies have shown that horseradish contains significant amounts of phenolic compounds with antioxidant properties (Tomsone, 2015). There are also scientific findings showing that both underground and above-ground parts of horseradish are valuable in this respect (Dekić et al., 2017). One of the most natural ways of plant treatment and extraction of valuable biologically active compounds is juice extraction, which does not use any chemicals. However, in order to prevent the loss of these natural biologically active compounds during longterm storage or conventional heat treatment ( $\mathrm{Su}$ et al., 2019), a good solution is the microencapsulation of juice.

Microencapsulation is the combination of a solid, liquid or vapour material with coatings to form small particles called microcapsules (Gharsallaoui et al., 2007). Spray drying is the most widely used encapsulation method. Different polysaccharides, proteins or lipids are used as wall materials, protect the biologically active compounds in the juice from the environment and prolong their lifespan until they are further added to one of the food matrices. Previous studies on the effectiveness of different types of horseradish products (microcapsules and pomace) in food matrices have yielded positive results (Tomsone et al., 2020).

The use of high-pressure processing (HPP) in the production of meat and meat products is a relatively new type of processing. The use of this technology inactivates microorganisms, while maintaining the physico-chemical properties and quality of meat and meat products and extending their shelf life (Cheftel and Culioli, 1997). High-pressure processing usually is applied to the pre-packaged product, which prevents secondary contamination of the product, as the product does not come into direct contact with the equipment and the environment during and after HPP. The main advantage of this method is low electricity consumption and reduced risk of environmental pollution. Rastogi et al. (2007) noted that high pressure technology is an environmentally friendly processing technology.

Combination of two or more shelf-life extension techniques (hurdles), such as the combination of several preservatives with physical methods, is used to increase the nutritional value and microbiological and sensory quality of the products (Leistner, 2000; Zhou et al., 2010). In the literature, there have been described more than 60 potential hurdle technologies that improve food stability and/or quality (Leistner and Gorris, 1995; Zhou et al., 2010; Rodrigues et al., 2016). Combination of herbal additives with HPP increases the antimicrobial effect and reduces the undesirable changes caused by high pressure (above $400 \mathrm{MPa}$ ) (Bajovic et al., 2012; Sazonova, 2020). There is a reason to assume that high-pressure treatment and microencapsulated biologically active substances would have synergistic effect. Therefore, the aim of this study was to evaluate the effectiveness of a combined high-pressure treatment and microencapsulated horseradish root and leaf juice on raw pork meat quality.

\section{MATERIALS AND METHODS}

The object of the study was pork meat (Musculus longissimus lumborum) cut into pieces and treated with microencapsulated horseradish root juice (S) and microencapsulated horseradish leaf juice (L). The amount of horseradish juice microcapsules added to the meat was calculated taking into account experiments performed by other researchers (Azman et al., 2015; Masoodi, 2016). For meat processing, horseradish root and horseradish leaf juice were microencapsulated using maltodextrin (DE 12) as a wall material. The ratio of wall material to horseradish juice was $1: 1$ (calculated on a dry basis). The working solution for meat treatment was prepared from microencapsulated horseradish root and horseradish leaf juice, using water as a solvent. When preparing a solution from microencapsulated horseradish root juice, the microcapsules were dissolved in water at a concentration of $1.3 \%$, but in the case of microencapsulated horseradish leaf juice $-0.13 \%$ concentration. Thus, the total amount of phenols was the same in both root and leaf solutions.

Raw meat was cut into $15 \mathrm{~mm}$ thick slices of $50 \pm 2 \mathrm{~g}$ each. The prepared solution was added to the meat (calculated at $1 \mathrm{ml}$ per $100 \mathrm{~g}$ of meat) and massaged into the meat with sterile hands for 5 minutes.

Half of the samples were treated under high pressure at 300 $\mathrm{MPa}$ for $15 \mathrm{~min}$ in a high-pressure processor ISO-Lab SFL-100-250-09-W (Stansted Fluid Power Ltd., UK).

Microbiological analyses. Total plate count (TPC) was determined according to the standard LVS EN ISO 48331:2014 Number of colonies at $30{ }^{\circ} \mathrm{C}$ with Pour Plate Technique (ISO 4833-1:2013), using nutrient agar (NA) (reference No 01-140-500), incubation at $30{ }^{\circ} \mathrm{C}$ for 72 hours under aerobic conditions.

Meat pH was determined according to the standard LVS ISO 2917:2004. The meat was minced, weighed in a beaker and poured with distilled water at a ratio of $1: 10$, stirred periodically for 30 minutes and then filtered through a filter paper. A Jenway $3520 \mathrm{pH}$ Meter (Jenway, EU) was used for measurement.

Meat colour was determined with a colour analyser - colorimeter Color Tec PCM/PSM (Accuracy Microsensors Inc., ASV) using a Cie L*a*b* system.

Meat moisture was determined in accordance with the LVS ISO 144: 1997 standard.

Meat water activity was determined with a LabSwift-aw (Novasina, Switzerland). Temperature during measurements was $22 \pm 1{ }^{\circ} \mathrm{C}$.

Hardness of the meat was determined using a texture analyser TA.HD.Plus (Stable Microsystems, UK). The WarnerBratzler shear device consisting of a knife blade and a base with a slot was used. The sample (slice of meat $3 \mathrm{~cm}$ wide, $2.5 \mathrm{~cm}$ thick) was placed in the centre of the platform. 
Blade at a speed $1 \mathrm{~mm} \cdot \mathrm{s}^{-1}$ sheared the test sample perpendicular to the meat fibre.

Statistical analyses. Results were analysed using the methods of mathematical statistics of Microsoft Excel. For data interpretation, one way analysis of variance (ANOVA) and the Tukey test for multiple comparison were used.

\section{RESULTS}

Total plate count. The changes in the number of TPC in the samples during storage are shown in Figure 1.

At the beginning of the experiment, the TPC in chilled pork was $1.99 \log$ CFU.g ${ }^{-1}$, but for the high-pressure treated control sample it was $1.75 \log \mathrm{CFU} \cdot \mathrm{g}^{-1}$. During storage up to day 14 , the TPC was significantly lower $(p<0.05)$ in HPPtreated samples than in untreated samples. On day 21, although the results of the treated samples were lower, no significant differences $(p>0.05)$ between the samples were established. After 21 days, TPC was similar in the highpressure and untreated samples. The results showed that the high-pressure and untreated control samples on days 28 and 35 had the highest TPC, but the critical limit of $5.0 \mathrm{log}$ CFU.g ${ }^{-1}$ (EC Regulation No 2073/2005) was not exceeded.

pH. At the beginning of the experiment, the $\mathrm{pH}$ of the meat was $5.44 \pm 0.02$. The added microencapsulated horseradish leaf and root juice did not change the $\mathrm{pH}$ of the meat. On the other hand, when meat was processed under high pressure, the $\mathrm{pH}$ increased, which is in agreement with the results of previous studies (Sazonova et al., 2017). The $\mathrm{pH}$ dynamics during the storage of the samples can be seen in Figure 2.

The performed statistical calculations show significant differences $(p<0.05)$ between high-pressure treated and untreated samples. However, there were no significant differences between the control sample and the samples treated with microencapsulated horseradish leaf and root juice $(p>$ $0.05)$. This applies to both high-pressure and untreated samples.

Water activity. At the beginning of the experiments, the water activity $\left(\mathrm{a}_{\mathrm{w}}\right)$ in chilled pork was $0.976 \pm 0.05$, indicating that the effect of HPP on bacterial lethality is high. Products with low $\mathrm{a}_{\mathrm{w}}\left(\mathrm{a}_{\mathrm{w}} \leq 0.92\right)$ reduce the efficiency of high-pressure treatment, because the microorganism cells are protected against the negative effects of pressure. Summarising the obtained results, it was concluded that the dynamics of water activity during storage in the high-pressure treated sample with microencapsulated horseradish leaf juice differed significantly $(p<0.05)$ from other samples. This sample had the lowest water activity during storage compared to other samples.

Moisture content. The moisture content of chilled pork before storage was $69.83 \pm 1.21 \%$. After adding microencapsulated horseradish leaf and root juice, the moisture content was $71.69 \pm 0.34 \%$ and $72.53 \pm 0.19 \%$, respectively.

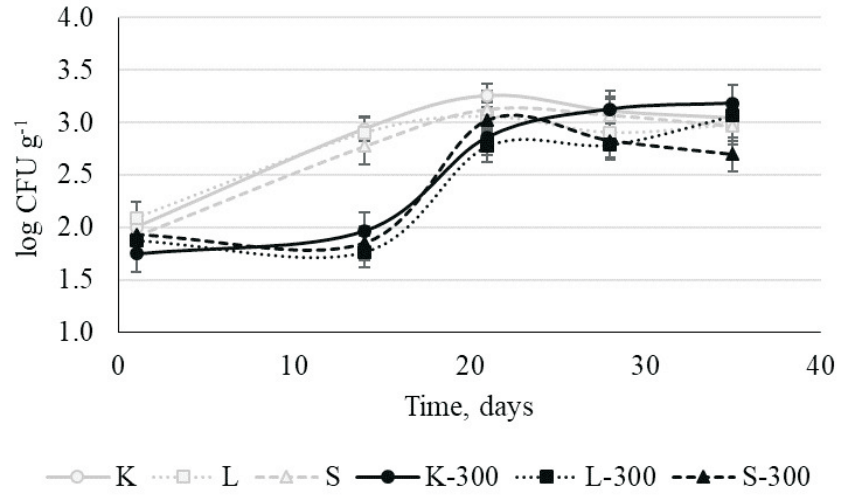

Fig. 1. The total plate count dynamics in samples during storage, where: K, control sample; L, raw meat sample with microencapsulated horseradish leaf juice; S, raw meat sample with microencapsulated horseradish root juice; K-300, control, high-pressure processing (HPP)-treated pork sample, $300 \mathrm{MPa} 15 \mathrm{~min}$; L-300, HPP-treated pork sample with microencapsulated horseradish leaf juice, $300 \mathrm{MPa} 15 \mathrm{~min}$; S-300, HPP-treated pork sample with microencapsulated horseradish root juice $300, \mathrm{MPa} 15 \mathrm{~min}$.

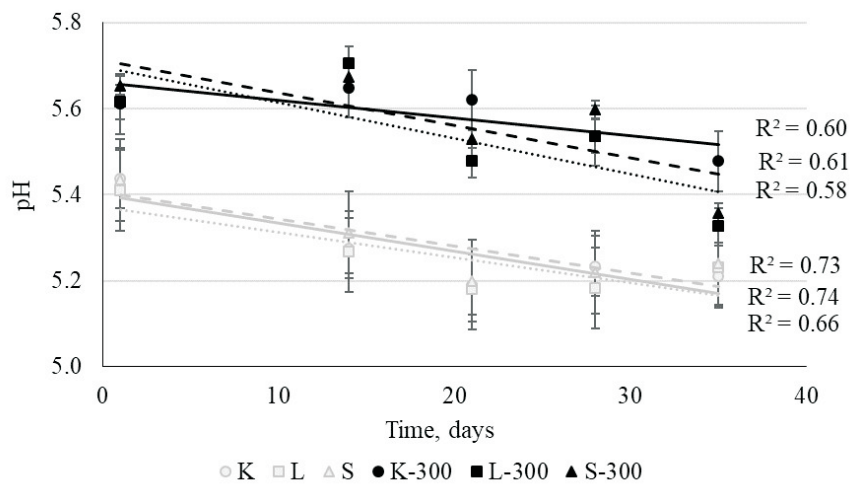

Fig. 2. $\mathrm{pH}$ changes during sample storage, where: K, control sample; L, raw meat sample with microencapsulated horseradish leaf juice; S, raw meat sample with microencapsulated horseradish root juice; K-300, control HPP treated pork sample, $300 \mathrm{MPa} 15 \mathrm{~min}$; L-300, high-pressure processing (HPP)-treated pork sample with microencapsulated horseradish leaf juice, $300 \mathrm{MPa} 15 \mathrm{~min}$; S-300, HPP-treated pork sample with microencapsulated horseradish root juice, $300 \mathrm{MPa} 15 \mathrm{~min}$.

During storage, the moisture content of meat samples did not change significantly $(p>0.05)$. After 35 days, the moisture content of the control sample in the vacuum pack was $69.70 \pm 2.87 \%$, for samples with microencapsulated horseradish leaf juice $-71.86 \pm 0.13 \%$, and for samples with horseradish root juice $-71.19 \pm 0.19 \%$. The moisture content of the samples treated with high pressure was as follows: $70.00 \pm 0.45 \%$ for the control sample, $70.16 \pm 0.59 \%$ - the sample with horseradish leaf juice and $71.80 \pm$ $0.27 \%$ - the sample with horseradish root juice.

Meat surface colour evaluation revealed that significant $(p<0.05)$ differences in the $\mathrm{L}^{*}$ value occurred between samples with different treatment applied and these changes did not depend $(p>0.05)$ on the added microencapsulated horseradish leaf and root juice or storage time (Fig. 3).

Meat hardness. After longer time of storage, less force was required to cut the meat, indicating that the meat became 


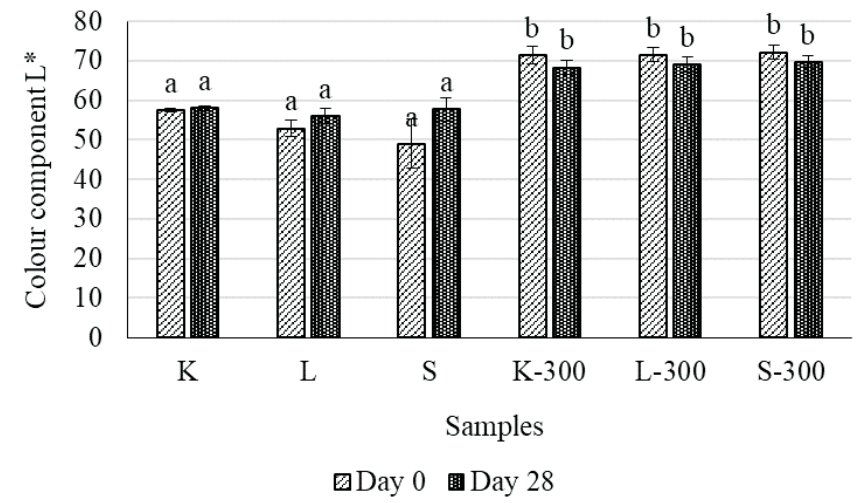

Fig. 3. Colour component $\mathrm{L}^{*}$ changes in samples, on the first and $28^{\text {th }}$ day of storage, where: K, control sample; L, raw meat sample with microencapsulated horseradish leaf juice; $S$, raw meat sample with microencapsulated horseradish root juice; K-300, control high-pressure processing (HPP)-treated pork sample, $300 \mathrm{MPa} 15 \mathrm{~min}$; L-300, HPP-treated pork sample with microencapsulated horseradish leaf juice, $300 \mathrm{MPa} 15 \mathrm{~min}$; S-300, HPP-treated pork sample with microencapsulated horseradish root juice, $300 \mathrm{MPa} 15 \mathrm{~min}$. Different letters indicate significant differences $(p<0.05), \mathrm{n}=12$.

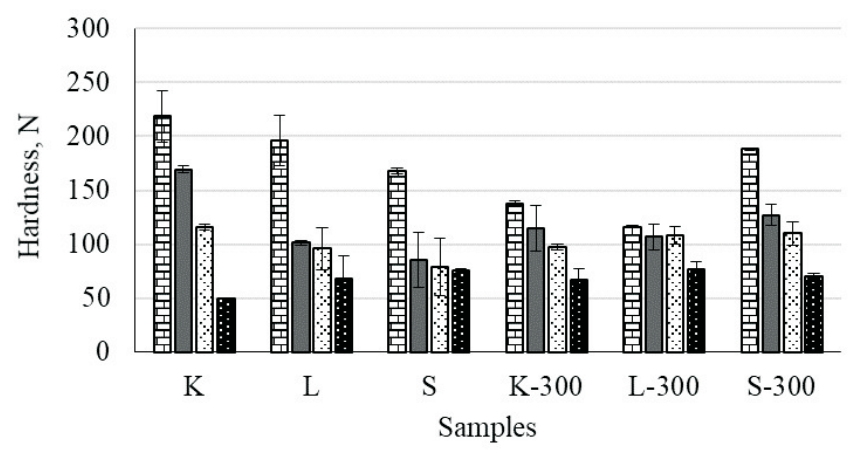

回Day 0 Day 14 Day 28 Day 35

Fig. 4. The hardness dynamic of sample during storage, where: K, control sample; L, raw meat sample with microencapsulated horseradish leaf juice; $\mathrm{S}$, raw meat sample with microencapsulated horseradish root juice; K-300, control high-pressure processing (HPP)-treated pork sample, $300 \mathrm{MPa} 15$ min; L-300, HPP-treated pork sample with microencapsulated horseradish leaf juice, $300 \mathrm{MPa} 15 \mathrm{~min}$; S-300, HPP,treated pork sample with microencapsulated horseradish root juice, $300 \mathrm{MPa} 15 \mathrm{~min}$.

softer. This trend was observed for all samples, regardless of the type of treatment used or the additives applied (Fig. 4).

\section{DISCUSSION}

Combined or hurdle technology uses a combination of two or more shelf life extension methods. This makes it possible to combine a number of preserving factors (hurdles), thus improving the microbiological quality and safety of food. In the case of highly efficient hurdle technology, a synergistic effect can be observed, in which factors increase each other's effects. When treating meat and meat products under high pressure, synergistic effects have been observed with antimicrobials. Also, in this study, it was shown that HPPtreated samples up to day 21 had lower TPC. As reported by
Garriga et al. (2002), this can be explained by increased mortality of microorganisms in HPP samples in proportion to the increase in pressure, but this does not occur after first-order kinetics and sometimes occurs at the end of the inactivation process. The most resistant microorganism cells, as well as damaged cells, can recover during storage (Bozoglu et al., 2004). The reaction of microorganisms in meat and meat products to HPP is variable and depends on the process parameters, such as pressure, temperature and treatment time, as well as product parameters such as $\mathrm{pH}$, $\mathrm{a}_{\mathrm{w}}$, salt content, and the presence of antimicrobials (Töpfl and Heinz, 2009; Rendueles et al., 2011; Hoover, 2016).

The resistance of meat to spoilage is ensured by $\mathrm{pH}$; as the $\mathrm{pH}$ becomes more acidic, the storage time of the meat increases due to the accumulation of lactic acid, as well as it significantly affects the development of microorganisms (Liepina et al., 2010). The $\mathrm{pH}$ level of meat and the rate of its decrease is influenced by biochemical processes before and after slaughter of animals, their effect on structural components in muscle cells, as well as connective tissue (Hughes et al., 2014). These changes apply to both highpressure and untreated samples. During the cooking process, the $\mathrm{pH}$ of the meat decreases, which is caused by physical and chemical changes in protein (Hamm and Deatherage, 1960), but HPP raises the $\mathrm{pH}$. Although the structure of proteins formed by high pressure and heat treatment may be different, the structural changes are similar (Ma and Ledward, 2004).

The optimal water activity for bacterial growth in meat is at least $\mathrm{a}_{\mathrm{w}}-0.91$ (Heinz and Buckow, 2010). The water activity of fresh meat ranges from 0.99 to 0.98 . A greater amount of free water in the product provides better conditions for the development of microorganisms. To reduce the water activity in meat and meat products, salt is often added, which increases the osmotic pressure in the product. In this way, the shelf life can be extended and the safety of meat products can be improved, as they become more resistant to the action of micro-organisms and the resulting spoilage. No such changes were observed in samples supplemented with microencapsulated horseradish leaf and root juice.

The $\mathrm{L}^{*}$ value of the meat colour was higher for samples treated at high pressure, and thus the colour of the meat was lighter. This is due to the fact that the protein myosin is sensitive to pressure and denatures at 180-300 MPa, giving a colour similar to cooked meat (Ma and Ledward, 2013). These colour changes can be caused by both protein aggregation, which affects the structure and surface properties, and by denaturation and/or oxidation of myoglobin (Hughes et al., 2014).

Meat became softer during its storage, irrespective of treatment. In accordance with Olivera et al. (2013), after 24 hours of post-mortem glycogen degradation in muscle tissue, meat stiffness decreases. This degradation is caused by proteolytic enzymes such as calpain and liposomal proteases (Dave and Ghaly, 2011), and is affected by storage time, temperature, as well as other factors including $\mathrm{pH}$. 


\section{CONCLUSIONS}

During storage up to day 14 , the number of TPC was significantly lower $(p<0.05)$ for high-pressure treated samples compared to untreated samples. On day 21 , although the results of the treated samples were lower, no significant differences $(p>0.05)$ were found between the samples. The $\mathrm{pH}$ of the meat was not significantly $(p<0.05)$ influenced by the added microencapsulated juice, but it was affected by high pressure treatment. The dynamics of water activity during storage in the high-pressure treated sample with microencapsulated horseradish leaf juice differed significantly $(p<0.05)$ from the other samples, while the moisture content in all samples was similar and almost did not change during storage. Experiments have shown that significant $(p<0.05)$ differences in the $\mathrm{L}^{*}$ value of the colour existed between treated samples, but they did not depend on the added microencapsulated horseradish leaf or root juice or storage time. Hardness decreased during storage, but no significant differences $(p>0.05)$ were found between samples.

\section{ACKNOWLEDGEMENTS}

This study was financially supported by the: European Regional Development Fund Post-doctoral Research Support Programme (project No 1.1.1.2/16/I/001) Research application "The changes of horseradish biologically active compounds and their bioavailability in an in vitro model of the human gastrointestinal tract as a result of technological processes" (No 1.1.1.2./VIAA/1/16/187); European Social Fund Latvia University of Life Sciences and Technologies (LULST) project No 8.2.2.0/18/A/014 "Development of LULST Academic Staff" (ES29); "Strengthening Research Capacity in the LULST," project Z-13 "Effect of High Pressure Processing on Pork Quality Indicators".

\section{REFERENCES}

Azman, N. A. M., Gordon, M. H., Skowyra, M., Segovia, F., Almajano, M. P. (2015). Use of lyophilised and powdered Gentiana lutea root in fresh beef patties stored under different atmospheres. J. Sci. Food Agric., 95 (9), 1804-1811.

Bajovic, B., Bolumar, T., Heinz, V. (2012). Quality considerations with high pressure processing of fresh and value added meat products. Meat Sci., 92 (3), 280-289.

Bertóti, R., Böszörményi, A., Alberti, I., Béni, S., M-Hamvas, M., Szõke, É., Vasas, G., Gonda, S. (2019). Variability of bioactive glucosinolates, isothiocyanates and enzyme patterns in horseradish hairy root cultures initiated from different organs. Molecules, 24 (15), 1-18.

Bozoglu, F., Alpas, H., Kaletunē, G. (2004). Injury recovery of foodborne pathogens in high hydrostatic pressure treated milk during storage. FEMS Immunol. Med. Microbiol., 40 (3), 243-247.

Cheftel, J. C., Culioli, J. (1997). Effects of high pressure on meat: A review. Meat Sci., 46 (3), 211-236.

da Silva Anthero, A. G., Comunian, T. A., Kurozawa, L. E., Pollonio, M. A. R., Hubinger, M. D. (2021). Chapter 7. Application of nano/microencapsulated ingredients in meat products. In: Jafari, S. M. B. T. (Ed.). Nanoencapsulation in the Food Industry.Vol. 6. Academic Press, pp. 305-343.
Dave, D., Ghaly, A. E. (2011). Meat spoilage mechanisms and preservation techniques: A critical review. Amer. J. Agric. Biol. Sci., 6 (4), 486-510.

Dekić, M. S., Radulović, N. S., Stojanović, N. M., Randjelović, P. J., Stojanović-Radić, Z. Z., Najman, S., Stojanović, S. (2017). Spasmolytic, antimicrobial and cytotoxic activities of 5-phenylpentyl isothiocyanate, a new glucosinolate autolysis product from horseradish (Armoracia rusticana P. Gaertn., B. Mey. \& Scherb., Brassicaceae). Food Chem., 232, 329-339.

Garriga, M., Aymerich, M. T., Costa, S., Monfort, J. M., Hugas, M. (2002). Bactericidal synergism through bacteriocins and high pressure in a meat model system during storage. Food Microbiol., 19 (5), 509-518.

Gharsallaoui, A., Roudaut, G., Chambin, O., Voilley, A., Saurel, R. (2007) Applications of spray-drying in microencapsulation of food ingredients: An overview. Food Res. Int., 40(9), 1107-1121.

Hamm, R., Deatherage, F. E. (1960). Changes in hvdration and charges of muscle proteins, during freeze-dehydration of meat. J. Food Sci., 25 (5), $573-586$.

Heinz, V., Buckow, R. (2010). Food preservation by high pressure. J. Fur Verbraucherschutz Und Leb. / J. Consum. Prot. Food Saf., 5 (1), 73-81.

Hoover, D. G. (2016). High pressure processing of food. In: Balasubramaniam, V. M., Barbosa-Cinovas, G., Lelieveld, H. L. M. (eds.). High Pressure Processing of Food: Principles, Technology and Application. Springer, pp. 19-37.

Hughes, J. M., Oiseth, S. K., Purslow, P. P., Warner, R. D. (2014). A structural approach to understanding the interactions between colour, water-holding capacity and tenderness. Meat Sci., 98 (3), 520-532.

Leistner, L. (2000). Basic aspects of food preservation by hurdle technology. Int. J. Food Microbiol., 55 (1), 181-186.

Leistner, L., Gorris, L. G. M. (1995). Food preservation by hurdle technology. Trends Food Sci. Technol., 6 (2), 41-46.

Liepiṇa, S., Jemeḷjanovs, A., Konošonoka, I.-H. (2010). Mikrobiālā piesārņojuma pakāpes noteikšana savvaḷas dzīvnieku (Capreolus capreolus un Cervus elaphus) gạ̦ā [Microbiological pollution rate of wild animal (Capreolus capreolus and Cervus elaphus) meat]. LLU Raksti, 25 (320), 102-115.

Ma, H., Ledward, D. A. (2004). High pressure/thermal treatment effects on the texture of beef muscle. Meat Sci., 68 (3), 347-355.

Ma, H., Ledward, D. A. (2013). High pressure processing of fresh meat — is it worth it? Meat Sci., 95 (4), 897-903.

Masoodi, F. A. (2016). Advances in use of natural antioxidants as food additives for improving the oxidative stability of meat products. Madridge $J$. Food Technol., 1 (1), 10-17.

Medjakovic, S., Zoechling, A., Vollmer, G., Zierau, O., Kretzschmar, G., Möller, F., Kolba, S., Papke, A., Opietnik, M., Kosma, P., Rosenau, T., Jungbauer, A. (2011). Indolylfuran, a potent aryl hydrocarbon receptor agonist from sauerkraut, interacts with the oestrogen pathway. Food Chem., 127 (4), 1764-1772.

Merlino, V. M., Borra, D., Girgenti, V., Dal Vecchio, A., Massaglia, S. (2018). Beef meat preferences of consumers from Northwest Italy: Analysis of choice attributes. Meat Sci., 143, 119-128.

Naczk, M., Shahidi, F. (2004). Extraction and analysis of phenolics in food. J. Chromatogr. A, 1054 (1-2), 95-111.

Oliveira, D., Steur, H. De, Lagast, S., Gellynck, X., Joachim, J., Oliveira, D., Steur, H. De, Lagast, S., Gellynck, X., Schouteten, J. J. (2020). The impact of calorie and physical activity labelling on consumer's emo-sensory perceptions and food choices. Food Res. Int., 133, 109166.

Olivera, D. F., Bambicha, R., Laporte, G., Cįrdenas, F. C., Mestorino, N. (2013). Kinetics of colour and texture changes of beef during storage. $J$. Food Sci. Technol., 50 (4), 821-825. 
Rastogi, N. K., Raghavarao, K. S. M. S., Balasubramaniam, V. M., Niranjan, K., Knorr, D. (2007). Opportunities and challenges in high pressure processing of foods. Crit. Rev. Food Sci. Nutr., 47 (1), 69-112.

Rendueles, E., Omer, M. K., Alvseike, O., Alonso-Calleja, C., Capita, R., Prieto, M. (2011). Microbiological food safety assessment of high hydrostatic pressure processing: A review. LWT - Food Sci. Technol., 44 (5), 1251-1260.

Rodrigues, I., Trindade, M. A., Caramit, F. R., Candošan, K., Pokhrel, P. R., Barbosa-Cánovas, G. V. (2016). Effect of high pressure processing on physicochemical and microbiological properties of marinated beef with reduced sodium content. Innov. Food Sci. Emerg. Technol., 38, 328-333.

Sazonova, S. (2020). Effect of High Pressure Processing on Pork Meat Quality. PhD thesis. Latvia University of Life Sciences and Technologies. $95 \mathrm{pp}$.

https://llufb.1lu.1v/disertacijas/LLU-tikla/Sanita-Sazonova_0011080_pro mocijas_darbs_2020_LLU_PTF.pdf (accessed 15.11.2021).

Sazonova, S., Galoburda, R., Gramatina, I. (2017). Effect of high pressure processing on microbial load in pork. Res. Rural Dev., 1, 237-243.

Su, D., Wang, Z., Dong, L., Huang, F., Zhang, R., Jia, X., Wu, G., Zhang, M. (2019). Impact of thermal processing and storage temperature on the phenolic profile and antioxidant activity of different varieties of lychee juice. Lwt, 116, 108578.

Received 22 March 2021

Accepted in the final form 10 November 2021
Tomsone, L. (2015). Investigation of Biologically Active Substances in Horseradish and Lovage. $\mathrm{PhD}$ thesis. Latvia University of LifeSciences and Technologies. 148 pp.

Tomsone, L., Galoburda, R., Kruma, Z., Majore, K. (2020). Physicochemical properties of biscuits enriched with horseradish (Armoracia rusticana L.) products and bioaccessibility of phenolics after simulated human digestion. Pol. J. Food Nutr. Sci., 70 (4), 419-428.

Töpfl, S., Heinz, V. (2009). New options for targeted product modification. Fleischwirtschaft Int., 3, 11-13.

Torrico, D. D., Hutchings, S. C., Ha, M., Bittner, E. P., Fuentes, S., Warner, R. D., Dunshea, F. R. (2018). Novel techniques to understand consumer responses towards food products: A review with a focus on meat. Meat Sci., 144, 30-42.

Wang, J., Zhang, M., Devahastin, S., Liu, Y. (2020). Influence of low-temperature ball milling time on physicochemical properties, flavor, bioactive compounds contents and antioxidant activity of horseradish powder. $A d v$. Powder Technol., 31 (3), 914-921.

Yordanov, D. G., Angelova, G. V. (2010). High pressure processing for foods preserving. Biotechnol. Biotechnol. Equip., 24 (3), 1940-1945.

Zhou, G. H., Xu, X. L., Liu, Y. (2010). Preservation technologies for fresh meat: A review. Meat Sci., 86 (1), 119-128.

\section{MIKROIEKAPSULĒTAS MĀRRUTKU SULAS UN AUGSTA SPIEDIENA APSTRĀDES KOMBINĒTĀ IETEKME UZ CŪKGAL̨AS KVALITĀTI UZGLABĀŠANAS LAIKĀ}

Augstspiediena apstrāde (high-pressure processing, $H P P$ ) ir piemērota patēētāju pieprasījuma pēc gaḷas produktiem ar minimālu termisko apstrādi nodrošināšanai, neapdraudot produkta drošību. Savukārt ārstniecības augiem piemīt antioksidantu un antimikrobiālas īpašības. Šī pētījuma mērḳis bija novērtēt šḳēršlı tehnoloǵijas pielietošanu, apvienojot mikroiekapsulētu mārrutku sakṇu un lapu sulu ar augsta spiediena apstrādi (300 MPa; 15 min), lai pagarinātu neapstrādātas cūkgaḷas uzglabāšanas laiku. Gaḷas uzglabāšanas laikā tika novērtēta ūdens aktivitāte $\left(\mathrm{a}_{\mathrm{w}}\right), \mathrm{pH}$, krāsa, cietība un mikrobioloǵiskie rādītāji. Uzglabāšanas laikā līdz 14. dienai mezofili aerobo un fakultatīvi anaerobo mikroorganismu skaits (MAFAm) HPP apstrādātajos paraugos bija ievērojami mazāks $(p<0.05)$, salīdzinot ar neapstrādātiem paraugiem. Savukārt 21. dienā MAFAm apstrādātos paraugos joprojām bija nedaudz mazāks, bet aprēkinini būtiskas atškikirības neuzrādīja. Cūkgaḷas paraugos ar pievienotām mikrokapsulētām mārutku sulām $\mathrm{a}_{\mathrm{w}}$ dinamika ievērojami atškīīās no citiem paraugiem. Uzglabāšanas laikā gaḷas paraugu cietība samazinājās, bet būtiskas atškirības starp tiem netika konstatētas. Savukārt gaḷas paraugu krāsas L* komponentes vērtību un $\mathrm{pH}$ būtiski neietekmēja pievienotā mikrokapsulētā sula, bet ietekmēja augstspiediena apstrāde. Apstrāde ar mikrokapsulētu mārrutku sulu pozitīivi ietekmēja gaḷas MAFAm un aw. 